\section{CHINA AND THE WORLD'S FIRST FREEDOM OF INFORMATION ACT: THE SWEDISH FREEDOM OF THE PRESS ACT OF 1766}

\section{LENA RYDHOLM}

\section{Abstract}

In 1766, the world's first freedom of information act: His Majesty's Gracious Ordinance Relating to Freedom of Writing

and of the Press was passed in the Swedish Diet, largely through the work of Anders Chydenius. Few people today realise that this had something to do with China. The image

of China as a distant utopia, a prosperous and politically stable country, had been created through accounts such as Jean Baptiste Du Halde's four volume Description géographique, historique, chronologique, politique, et physique de l'empire de la Chine et de la Tartarie chinoise. In Sweden, politicians Anders Nordencrantz and Anders Chydenius, basing their arguments on Du Halde's descriptions, claimed that the freedom of writing, of the press and of information had been in existence in China since ancient times, and had largely contributed to the wealth and stability of China. In this paper I examine the political pamphlets written by these two Swedish politicians to show how they used China as an example to strengthen the arguments for a Freedom of the

Press Act in Sweden.
Lena Rydholm is Professor of Chinese in the Department of Linguistics and Philology at Uppsala University; e-mail: lena.rydholm@lingfil.uu.se. 


\section{Introduction}

In 1766, His Majesty's Gracious Ordinance Relating to the Freedom of Writing and of the Press ${ }^{1}$ was passed in the Swedish Diet. This act allows citizens the freedom of writing, the freedom of the press, and in addition the freedom of information, public access to official documents. Sweden (including Finland at that time), was the first country in the world to incorporate a Freedom of Information Act (FOIA) in its constitution. Since then, this Act has been revised several times but has remained a founding principle of Swedish democracy. According to Manninen $(2006,18)$ this Act can partly explain why the European North "has become the world's least corrupt area and, concurrently, exceptionally socially responsible and committed to democratic principles."

Today, most Swedish people take the freedom of speech, of the press and of information for granted. Few can imagine that the passing of this first Act had something to do with China, or rather, a certain image of China in Sweden in the 18th century. Neither Swedish media scholars nor sinologists have taken any interest in this issue in recent years. It came to my attention through a lecture by Prof. Marie-Christine Skuncke (Dept. of Literature, Uppsala University and SCAS, Uppsala). ${ }^{2}$ I decided to examine political pamphlets written in the 18th century that contained references to China. I wrote a paper for the conference "Global Media Worlds and China" at Uppsala University in 2011 that has now turned into this article. My study gives an insight into the political influence of the image of China in Sweden on the passing of Sweden's first FOIA. I have examined how an image of China as the land of freedom, of writing and of the press was created in political pamphlets written by two of the most influential advocates of passing a Freedom of Writing, of the Press, and of Information Act in the Swedish Diet of 1765-66, politicians Anders Nordencrantz and Anders Chydenius.

\section{The Swedish Form of Government during the Age of Liberty (1719-1772)}

At the beginning of the 18th century, the Swedish King had lost much power due to the costly and disastrous wars of the previous King Karl XII that had greatly reduced Sweden's influence in the region. A new constitution moved power away from the King in favour of a parliament, the Swedish Diet, consisting of four Estates (clergy, nobility, burghers and peasants). There were two parties in the Diet, the conservative Hat party in power and the radical opposition, the Cap Party, which supported the freedom of writing, of information and of the press. At that time, it was forbidden not only to publish texts about the foundations of affairs of the state but even to write down thoughts on such matters on paper for private use (Manninen 2006, 22). All publications were subject to censorship. But State Censor Niklas von Oelreich was quite liberal. Some claim it was because he supported freedom of the press, since he joined the Cap Party in 1765; while others think it was because he got 10 percent of the printing cost of the texts he approved (Virrankoski $1995,88)$. Oelreich's liberal treatment of publications played an important role in opinion-making and debate in books and pamphlets published between 1760 and 1772 (Lindberg 2003, 17).

No single doctrine dominated the political debate, but words like freedom, citizen and rights became political slogans (Lindberg 2003, 14, 21). According to 
Lindberg (2003, 16-17), there were many competing ideas at the time, and personal interests and efforts, even mere coincidences, may have played a great part in the political decision-making. Anders Nordencrantz and Anders Chydenius were two important political thinkers concerned with both economic theory and the freedom of writing and of the press. Nordencrantz was inspired by contemporary political developments in England and France and by philosophers like Montesquieu, Hume and others (Magnusson 2003, 34), and Chydenius was inspired by Nordencrantz. They both chose China as a major example to support their arguments for the freedom of writing, of the press and of information (Skuncke 2003, 36).

\section{The Image of China in Sweden in the 18th Century}

During the Age of Liberty in Sweden, the influence of the image of China became important in Swedish society, culture and politics. The Swedish East India Company shipped porcelain, silk, tea and other popular products from China. King Adolf Fredrik built a "Chinese castle" in the garden of the royal summer palace Drottningholm, as a birthday present for Queen Louisa Ulrika in 1753; "chinoiserie" was in vogue. Even in politics, the image of China came to play an important role. There could be many reasons for Chydenius and Nordencrantz to use China as an example. The image of China's wealth of resources and population had earlier been created in accounts by Marco Polo, Mendoza and others. The most important work on China of in 18th century Europe was the French Jesuit Jean Baptiste Du Halde's monumental Description géographique, historique, chronologique, politique, et physique de l'empire de la Chine et de la Tartarie chinoise, published in Paris in 1735 (hereafter abbreviated Description de la Chine). The first abridged English version, translated from French by Richard Brookes, was published by J. Watts in London in 1736 as The General History of China: Containing a Geographical, Historical, Chronological, Political and Physical Description of the Empire of China, Chinese-Tartary, Corea and Thibet, Including an Exact and Particular Account of their Customs, Manners, Ceremonies, Religion, Arts and Sciences (Löwendahl 2008, 194). ${ }^{3}$ Du Halde's Description de la Chine in four volumes, almost 3000 pages, is an encyclopedic description of everything important to know about China from the viewpoint of the Jesuits: general history, form of government, administration, official titles, ceremonies, punishment of crimes, military forces, arms, artillery, geography, provinces, minority peoples, neighbouring countries, agriculture, trade, manufacture of silk, porcelain, paper, ink, book printing, religion, mathematics, astronomy, medicine, poetry, extracts from novels and the five classic etc. In Description de la Chine, China is a peaceful, prosperous country that has managed to persist for 4000 years, much thanks to the upholding of its ancient laws and customs.

China has this Advantage over all other Nations, that for 4000 years, and upwards, it has been govern'd, almost without Interruption, by its own Native Princes, and with little Deviation either in Attire, Morals, Laws, Customs, or Manners, from the wise Institutions of its first Legislators. As the Inhabitants find within themselves every thing necessary for the Convenience and Delight of Life, so wanting no foreign Assistance, they have always affected a Shyness to the Commerce of Strangers (Du Halde 1736, 2, 1; Transl. in Watts 1741, 2, 1). 
Sweden was a monarchy and in that sense similar to China. But the Swedish King's authority was very limited at that time and political power rested largely with the Parliament (Skuncke 2004, 81). Sweden was much less successful in terms of political stability, wealth and population, which explains the interest in using China as an example.

Many Cap party politicians in the early 1760s saw England as a model of freedom of writing and of the press, (since the English office of censor had been abolished, when the Censor Gilbert Mabbot voluntarily resigned in 1649, Manninen 2006, 51). But no law established this freedom in England. In Description de la Chine, China, in contrast, appeared to have already included the freedom of expression in its laws: "Notwithstanding the great Power with which the Emperor is invested, the Law allows the Mandarins, whenever he commits any Faults in his Administration, to represent them to him in an humble manner, and to lay before him the Inconveniences which they may occasion in the Government" (Du Halde 1736, 2, 14-15; Transl. in Watts, 2, 17-18). Naturally, such passages in Du Halde's work would appeal to politicians in the Nordic countries advocating the freedom of expression, such as Nordencrantz and Chydenius. But these kinds of statements in Du Halde's work constitute a fraction of all the information he provides on China in these four volumes. In addition, Du Halde himself had censored his source material, letters and memoirs from Jesuits in China. According to Löwendahl (2008, 1, 180): “Du Halde had removed material unsympathetic to the Chinese or to the Jesuits in editing the Jesuits' letters from China, initially in Lettres édifiantes and secondly for this Description." In addition, the descriptions of conditions in China in Du Halde's work were quite removed from Chinese reality: "Many sections, including geographical and historical chapters, are altogether inadequate, nor are the accounts of the government and social structure at all satisfactory" (Löwendahl 2008, 1, 180-81).

Finally, using China as an example had the advantage that one's opponents were hard pressed to prove that one was wrong since China was so far away and few, if any Swedish politicians, had actually been there; nor had Nordencrantz and Chydenius. Both these politicians would claim that China already had freedom of writing, of the press and of information. Nordencrantz wrote in a political pamphlet Oförgripeliga tankar om Frihet i bruk af Förnuft, Pennor och Tryck [Thoughts about the Freedom to use Reason, Pens and Printing] about the merits of the Peking Gazette. Chydenius published the political pamphlet Berättelse om Chinesiska Skrif-friheten [An Account of the Chinese Freedom of Writing], elevating the Chinese legal system and the wise Chinese emperors of the past who allowed their subjects the freedom of writing. China was used as an example by both politicians to strengthen their arguments in the debate on the Freedom of Writing, of the Press, and of Information Act in the Swedish Diet of 1765-66. Largely through the work of Chydenius, they were successful.

\section{Nordencrantz and the Freedom of Writing, of the Press and of Information}

Anders Nordencrantz (1697-1772) was a successful self-made businessman. After studying trade and commerce in London, he returned with radical ideas about society and economy. In 1729, he became a Diet member of the Burgher Estate. Nordencrantz was a prolific writer of political pamphlets and often had 
problems with censorship. In 1730, he tried to publish his economic treatise $A r$ cana Oeconomiae et Commercii [The Secrets of Economy and Commerce], in which he also demanded freedom of writing and of the press, but the work was banned by the Censor until that chapter had been removed (Virrankoski 1995, 175). For Nordencrantz, the freedom of writing and of the press was also important for other reasons than his own texts being censored. He argued that history must be made public to avoid repetitions of past mistakes; this would prevent despotism through revealing the cruelty and violence of despotic rulers (Hallberg 2003, 343, f 22). In addition, Nordencrantz feared the power of public opinions based on ignorance and prejudices, and advocated free public debate and freedom of the press to put opinions to the critical test and reveal the truth (Hallberg 2003, 344). He did not, however, want a complete abolition of censorship. The Censor should answer to the Estates instead of to the government (Manninen 2006, 39), and theological works should be censored by the Church.

In 1756, Nordencrantz wrote several political pamphlets. His Oförgripeliga tankar om Frihet $i$ bruk af Förnuft, Pennor och Tryck [Thoughts about the Freedom to use Reason, Pens and Printing] was banned by the Censor (Virrankoski 1995, 87). In this pamphlet, Nordencrantz claims that almost all text, except the repulsive, should be published, even state subversive texts, so that their erroneous ideas could be publicly refuted (Virrankoski 1995, 177). ${ }^{4}$ Nordencrantz claimed that censorship had "impeded Sweden's development with regard to freedom, security, arts and science and left Sweden more than a hundred years behind other peoples; all this was the doing of a single authority and individual interests that can not withstand light and truth, since the spirits of darkness require darkness." 5 This was criticism directed at the corruption of the Hat Party in power. Nordencrantz was critical of the state subsidies to ineffective industries run or controlled by Hat party members, and the secrecy and inefficiency of the Hat Party that controlled bureaucracy (Lindqvist 1996, 406). His anger with the Hat Party may also have had to do with his personal financial situation. Nordencrantz lost a large part of his fortune, being forced to sell his estate for paper bills of sinking value caused by the inflation policy imposed by the Hat Party (Herlitz 2003, 132). He became a major enemy of the Hat party in the 1760s, when he told the Swedish Diet that the reason for the inflation and dramatically sinking value of the currency was the excessive printing of bills (Herlitz 2003, 131). The Hat Party lost control of the Swedish Diet largely due to Nordencrantz having exposed its protection of certain groups within the Swedish nobility, manipulation of the currency and other faults (Lindqvist 1996, 408-9).

When the Cap Party gained power in 1765-66, Nordencrantz helped stage a deflation policy and punish the officials responsible for the inflation (Herlitz 2003, 132). Nordencrantz was a very active and aggressive politician late into his old age. He continued to write texts criticising individual Hat politicians, accusing them of manipulating the currency for their own personal gain and of being "evil and greedy scammers, thieves and robbers"' (Lindqvist 1996, 516).

\section{Nordencrantz and the Image of the Peking Gazette}

In the 1760s, with the liberal Censor von Oelreich, public opinion started to turn in favour of freedom of writing. In 1761, Nordencrantz's Oförgripeliga tankar om Frihet i bruk af Förnuft, Pennor och Tryck, samt huru långt Friheten derutinnan i et 
fritt Samhälle sig sträcka bör, tillika med påfölgden deraf [Thoughts about the Freedom to use Reason, Pens and Printing, and How Far this Freedom Should Be Extended in a Free Society, along with its Consequences] from 1756 was finally approved for publication (Virrankoski 1995, 87). In this pamhlet Nordencrantz claims that the freedom of writing and of the press provides the most efficient means of a free people to ensure government by reason and righteousness and to prevent corruption.

Reason through pens and printing provides the most sophisticated means through which the secret measures used by many free peoples' government to rule in a way that is invisible for the eyes of the people can be uncovered; and even though [the government's] actions are visible, the driving forces behind them are incomprehensible for the general public, but never for the reason accomplished by the aid of pens and printing. These means [pens and printing] are like the apple of the eye, that a free people's legislative authority should cherish, and it should be an essential part of its own authority and interest to be associated with this [the freedom of writing and of the press] (Nordencrantz 1756, 9).

In this political pamphlet, Nordencrantz used China as a major example of the freedom of the press and of information. He quoted a long passage in French in vol. 2 of Description de la Chine about the Peking Gazette to praise its merits.

In a word nothing can be more instructive, and more capable of keeping the Mandarins in order, and prevent the Faults they might be guilty of, than the Gazette which is printed every Day at Peking, and dispersed from thence into all the Provinces: There is nothing inserted in it but what has reference to the Government; and as the Chinese Government is absolute Monarchy, and the most trifling Affairs are brought before the Emperor, it contains nothing but what may be very serviceable to direct the Mandarins in the Exercise of their Office, and instruct the Learned as well as the Vulgar.

It contains, for instance, the Names of the Mandarins that have been deprived of their Offices, and for what Reason: One for being negligent in gathering the Emperor's Tribute, or for squandering in any way; another because he was too indulgent or too severe in his Punishment; this for his Oppression, that for want of Talents to govern as he ought. If any Mandarin has been raised to a considerable Office or been depressed; or if he has been deprived, for any Fault, of the Annual Pension that he ought to receive of the Emperor, it is immediately put into the Gazette.

It speaks likewise of all Criminal Affairs for which Persons are capitally condemned, and likewise the Names of the Officers who fill the Places of the Mandarins that were removed, as also the Calamities that happened in such and such a Province, and the Assistance given by the Mandarins of the Place in pursuance of the Emperor's Order; it likewise contains the Expences disbursed for the Subsistence of the Soldiers, the Necessities of the People, the Publick Works, and the Benefactions of the Prince; there are also the Remonstrances of the Supreme Tribunals, which have been made to the Emperor concerning his own Conduct, or his Decisions. 
They therein mention the Day that the Emperor tilled the Earth, that they may excite Emulation in the Minds of the People, and inspire those who govern them with a Love of Labour and Application for the Culture of the Fields; they mention likewise the Time of the Convention of the Grandees at Peking, and all the Chief Mandarins of the Tribunals, that they may be instructed in their Duty. There you may find the Law and new Customs that have been established, the Praises and Reprimands given by the Emperor to a Mandarin: For instance, such a Mandarin has not a very good Reputation, and if he does not amend he will be punished.

In short the Chinese Gazette is made in such a manner that it is very useful to instruct the Mandarins how to govern the People as they ought, for which reason they read it constantly; and as it gives an account of all the public Affairs that are transacted in this vast Empire, the greatest part commit to writing their Observations upon things that it contains, which may direct them in their Conduct (Nordencrantz 1756, 15-16; Du Halde 1736, 2, 49-50; Transl. in Watts 1741, 2, 69-71).

Nordencrantz obviously saw the Peking Gazette as an effective means for the people to access information, and to monitor the authorities, as well as for the state to control the government officials' behaviour. It is perhaps no wonder that Nordencrantz, being so angry with the Hat party politicians' corruption, would welcome a journal like the Peking Gazette in Sweden to publicly expose the lack of virtue, the crimes and the misdeeds of the Hat politicians, these "evil and greedy scammers, thieves and robbers." He would probably want to see them publicly disgraced and punished, just like the Chinese officials in the Peking Gazette. However, when Nordencrantz quoted Du Halde's entry on the Peking Gazette, he omitted the final lines in Du Halde's text, which are the following:

Nothing is printed in the Gazette but what has been presented to the Emperor, or comes from the Emperor himself; those who have the care of it dare not add a Title thereto, nor even their own Reflections, upon pain of Corporal Punishments. In 1726 a Writer of a Tribunal, and another Writer, who was employed at the Board of the Post-office, were condemned to Death for having inserted Circumstances in the Gazette that were found to be false: The Reason upon which the Tribunal of Criminal Affairs founded their Judgment, was, that he had failed in Respect to his Majesty, and the Law declares that whoever fails in Respect to his Majesty deserves Death (Du Halde 1736, 2, 50; Transl. in Watts 1741, 2, 71).

This final passage in Du Halde's entry about the Peking Gazette obviously did not serve the political purposes of Nordencrantz, so he omits the part about censorship. He would not want the Swedish King to become the "supreme censor," to hold the authority held by the Chinese Emperor in this respect. Nordencrantz's discourse on the freedom of writing, of the press and of information in Sweden was based on free public debate, on putting different opinions to the critical test to reveal the truth. This certainly involved the right to publish one's own "reflections" and political views, the right for any citizen to publicly debate any issue. If Sweden were to implement the Chinese laws described in Du Halde's entry about the Peking Gazette, that is, that any personal "reflections" were prohibited on pain 
of corporal punishment or death-then Nordencrantz, with his large production of aggressive pamphlets full of criticism of the authorities would probably be among the first to be beheaded. Nordencrantz cited only the part of Du Halde's entry about the Peking Gazette that suited his political agenda, providing his readers with an idealised view of the Peking Gazette, and of the freedom of the press and of information in China at the time.

In Sweden in the 18th century, Riksdagstidningar [Diet Journals] were published containing information about decisions made by the Diet, but no political analysis, debate or critique (Manninen 2006, 39) at that time. These journals rather served to strengthen the power and influence of the Diet. The Peking Gazettes were bulletins that copied word for word imperial records, imperial edicts and memoranda to the throne and the like, that had been approved for publishing and were provided by the Imperial Grand secretariat; they were published without any alterations and contained no news items written by journalists, and no analysis or debate whatsoever (Fang 1997, 212). The Peking Gazettes strengthened the Emperor's power and influence and control of the officials. Nordencrantz probably did not recognise the resemblance between these two bulletins in this regard.

In 1759, Nordencrantz published a memorandum of over 700 pages addressed to the Estates of the Swedish Diet of 1760 in which freedom of the press is the basic notion (Skuncke 2003, 34). In this memorandum, he again uses the Peking Gazette as an example in the political debate (Nordencrantz 1759, 242-243). This memorandum was initially banned but was finally approved and about a 1000 copies were distributed among the Estates (Malmström 1900, 13-14), thus making the Peking Gazette known to all members of the Estates. The debates about the freedom of writing, of the press and of information in the Diet of 1760-62 led to the publishing of several memoranda to the Diet (Virrankoski 1995, 176-9). But a major change in legislation had to wait for Chydenius and the Swedish Diet of 1765-66.

\section{Chydenius and the Image of China as the Land of Free Trade and Freedom of Writing}

Anders Chydenius (1729-1793), a Finnish priest, played a crucial role in the development of the first freedom of writing, of the press and of information act in Sweden. Being a man of the Enlightenment with wide learning, he was not only a priest but also a farmer, and he practiced medicine (Manninen 2006, 22). His political career started with an interest in economic issues. Chydenius was committed to helping the peasants and merchants of his poor home region in Finland to be relieved from trade barriers (Manninen 2006, 32). When the Cap party won the elections, Chydenius became a member of the Clergy Estate in the Swedish Diet of 1765-66 in Stockholm. In the Diet, young Chydenius became "the loudest and most prolific speaker of the Priest stand." (Lindqvist 1996, 421), and published several political pamphlets. In Chydenius's most important work on economic theory, Den nationnale winsten [The National Gain] of 1765, he advocated free trade and the free market (before Adam Smith's An Inquiry into the Nature and Causes of the Wealth of Nations). He was opposed to all kinds of oppression and lack of freedom. Hence he criticised slavery, and in spite of being a priest he also believed in religious tolerance and played a significant part in the Diet of 1779 when the Swedish Religious Freedom Act was passed (Knif 2003, 167). 
Chydenius, just like Nordencrantz, turned to a utopian view of China for political arguments. In 1765 he published Källan til Rikets wan-magt [The Source of the Impotence of the Kingdom], in which he blamed Sweden's poverty and falling currency on the lack of free trade and claimed that China's wealth could be attributed to the lack of trade barriers (he was eventuallly successful in abolishing some of the trade barriers in Sweden).

China is the richest Nation in the entire world, and is therefore an indisputable evidence, where Cities have no privileges, and there is no difference between City and Country trade, therefore the entire country is like a city, and all cities are like the most wonderful country. There are no Fences and Customs, therefore the Crown and its subjects each enjoy sufficient richness (Chydenius 1765, 5).

When Chydenius had become a Diet member in 1765, he had quickly realised that to achieve political success there was an important prerequisite: the freedom of information, of writing and of the press. To influence the debates and decision-making in the Diet, you needed access to the meeting protocols and records of the Diet and its committees. In his memoirs Chydenius, just like Nordencrantz complains about the secrecy of the Hat Party which made it difficult for the Cap party to gain influence. ${ }^{6}$ And, to influence public opinion, the freedom of writing and of the press was required. In his memoirs, Chydenius wrote about the insights he gained from reading Nordencrantz's Oförgripeliga tankar om Frihet i bruk af Förnuft, Pennor och Tryck, using Nordencrantz's "apple of the eye" metaphor: "[Nordencrantz's texts] had already opened my eyes, so that I considered it [the freedom of the press P.V.] the apple of the eye of a free country." ${ }^{7}$ Nordencrantz's expression is again used in Chydenius's Berättelse om Chinesiska Skrif-friheten [An Account of the Chinese Freedom of Writing] (Chydenius 1766, A5).

The memorial on the Freedom of Writing and of the Press was handed in to the Swedish Diet on the 12th of June, 1765, signed by the Finn Anders Kraftman, Cap Party member of the Clergy Estate. According to Chydenius's autobiography and research into the various revised versions of the text, it has been established that the memorial was in fact written by Chydenius (Schauman 1908, 158-9). By not signing the memorial himself, Chydenius could be appointed head of the Diet committee assigned to deliberate and draft an act to be presented to the Diet. The committee included representatives from all the Estates, but Chydenius had no problem in finding striking arguments in the fierce debate in the committee, and later in the Diet (Virrankoski 1995, 183-196).

Chydenius was more radical than Nordencrantz. He argued for the complete abolition of pre-printing censorship (with the exception of religious texts). Just like Nordencrantz, he believed that the truth is gained through free public debate and the competition of ideas and arguments (1765; Schauman 1908, 518-19) and that this method was used in China. He published Berättelse om Chinesiska Skrif-friheten [An Account of the Chinese Freedom of Writing] in April 1766, ${ }^{8}$ arguing that the cause of China's wealth and happiness of the people was the Chinese freedom of writing. After intense debates in the Diet of 1765-66, Chydenius's hard work paid off. On the 2nd of December 1766, Sweden's first Freedom of Writing, of the Press and of Information Act was passed in the Diet, based on the ideas and formulations by Chydenius in his memorial, and in the protocols and drafts that he had formulated 
in the committee (Virrankoski 1995, 193). Except for religious texts, censorship was abolished, official documents became accessible to the public, and the act was even proclaimed part of the Swedish constitution (Virrankoski 1995, 193). According to Schauman (1908, 159-60), the successful passing of this act depended on two major factors: the skilful work of Chydenius in the Diet committee preparing the act and Chydenius's political pamphlet Berättelse om Chinesiska Skrif-friheten.

\section{Chydenius' Pamphlet on Freedom of Writing}

Berättelse om Chinesiska Skrif-friheten: Öfversatt af danskan [An Account of the Chinese Freedom of Writing: Translated from Danish] is a political pamphlet that consists of two parts: a dedication written by Chydenius and a translation from Danish into Swedish by Chydenius of the entry "Om Frihed at skrive" [About the Freedom of Writing] in Friderich Lütken's Chapter 1, "Nogle Chinesiske StatsRegler og Oeconomiske Maximer eller Skikke: Uddragne af le Pere du Halde" [Some Chinese Rules of State and Economic Maxims or Customs: Extracts from Father Du Halde] in Oeconomiske Tanker till hoiere Eftertanke [Economic Ideas for Deeper Reflection] (Lütken 1759, 8-21).

According to Schauman $(1908,491)$, Lütken was an important writer of economic theories in Denmark at the time, who had problems with the censorship and had therefore translated and re-worked parts of Du Halde's Description de la Chine to promote the freedom of writing in Denmark. When comparing Lütken's text with Du Halde's, there are indeed passages in Du Halde's vol. 2 that have been re-worked and used in Lütken's work (as discussed in Examples 2 and 3 below), passages that in turn were translated into Swedish by Chydenius in his pamphlet. ${ }^{9}$

Berättelse om Chinesiska Skrif-friheten, begins with a dedication to "His Royal Highness Prince Gustaf Crown Prince of the Kingdom of Svea," who later became King Gustaf III of Sweden. In the dedication (1766, A2-A5), Chydenius asks the Prince, whom he addresses as "merciful master," "precious Prince" etc., to look mercifully upon the suggestions in his pamphlet. In this dedication, he stated his arguments for learning from the Chinese. According to Chydenius, China was the wealthiest country in the world with regard to commodities and population, and the reasons for China's wealth, the happiness of its people and the persistence of its government through millennia had nothing to do with habits, climate or fertility, as most European might think. These, according to Chydenius, were mere coincidences. Chinas success had been achieved through quite simple measures advocated by its rulers that, according to Chydenius, would have the same effect if implemented in any kingdom. One of these measures, often scorned by rulers, but which to the contrary had strengthened the throne in China, was the freedom of writing. According to Chydenius, the freedom of writing, as introduced in his pamphlet, had become "en ögnasten" ["the apple of the eye," using Nordencrantz's expression] of the constitution of China. He signed the dedication: "With the deepest reverence until my last breath remaining, Your Royal Highness's most obedient and faithful servant, Anders Chydenius" (1766, A5). Chydenius was wise to try to enrol the Prince's support for the freedom of writing, though this obviously was to no avail. In 1772, King Gustav III managed to overthrow the constitution and with it the first Freedom of Writing, of the Press and of Information Act made possible by Chydenius's work, replacing it with a new Act that restricted press freedom. But the Act of 1766 formed the foundation for subsequent laws in 1809-12 (Virrankoski 1995, 196). 
The main part of Berättelse om Chinesiska Skrif-friheten consists of Chydenius's translation of Lütken's "The Freedom of Writing," which in turn is based on a few passages in vol. 2 of Description de la Chine. More than one quarter of Du Halde's vol. 2 (1736, 2, 459-738) consists of an "imperial collection." ${ }^{10}$ It contains statements, instructions and the like by certain emperors and admonitions by certain wise ministers concerning good or bad government and so on. Certain passages in this collection are accounts of emperors encouraging their ministers to counsel them, or even criticise the government, and the emperor himself, if they find faults. The main part of Lütken's text consists of a selection of such examples from the collection that he used to argue for the freedom of writing in Denmark. Chydenius in his turn used his Swedish translation of Lütken's text to strengthen his argument in the debate about the freedom of writing and of the press in Sweden. When I compared the passages in Du Halde's original text in French with Lütken's translations of these passages into Danish and finally with Chydenius's translation of Lütken's Danish versions into Swedish, it is evident that both Lütken and Chydenius used their source in a way that suited their political agenda, thereby helping to shape a certain image of the freedom of writing in China in Denmark and in Sweden.

\section{Analysis of Three Examples in the Translations by Lütken and Chydenius}

Considering the scope of the article, I have included only three examples. A systematic comparison of all the relevant passages in Du Halde's, Lütken's and Chydenius's texts can no doubt reveal more interesting features (the investigation could also be extended to include comparisons with Du Halde's Western and Chinese sources). However, the three examples below suffice to show that a certain form of the freedom of expression in China described in Description de la Chine went through several revisions on its way through Lütken's Danish translation, and then through Chydenius's Swedish translation of Lütken's text, before it reached the Swedish readers. The abbreviated or re-worked "translations" by Lütken and Chydenius were adapted to their political purposes, to the political debate in the Nordic countries and to the intended readers.

Example 1. When comparing Lütken's About the Freedom of Writing with Description de la Chine, it is evident that Lütken did not simply translate a particular section but has summarised the parts of a chapter or document that suited his agenda. This first example comprises the very first lines in the second chapter of Du Halde's vol. 2., dealing with the authority of the Chinese Emperor. ${ }^{11}$

There is no Monarchy more absolute than that of China: The Emperor has an absolute Authority [here a line in Du Halde's French original is missing in Watts's translation that could be translated as: "and to judge by appearances, he is a kind of divinity"], and the Respect which is paid to him is a kind of Adoration; his Words are like so many Oracles, and his Commands are as strictly and readily executed as if they came directly from Heaven; none are admitted to speak to him but on their Knees, not even his elder Brother, unless he commands it to be otherwise; nor any, but the Lords that accompany him, are allowed to stand before him, and to put one Knee only to the Ground when they speak to him. [...] the Mandarins, 
the Grandees of the Court, and the Princes of the Blood not only prostrate themselves in the Presence of the Emperor, but they do it also before his Chair or Throne, and every thing that is for his Use, kneeling down even before his Habit or his Girdle (Du Halde 1736, 2, 10-11; Transl. in Watts 1741, 2, 12-13).

Lütken re-worked this passage from the French original by Du Halde (1736, $2,10-11)$.

The emperors of China are absolute sovereigns and have absolute power in all respects: and the people are obedient, easily led, contented and hardworking, and have a completely divine esteem for their emperor, so the emperors surely can do whatever they please, so long as they observe the Laws and comply with the Constitution.

But their ancient Chronicles prove with innumerable examples that, things have never gone well for those who have transgressed them [the laws], and that things have always gone well as long as the rulers have observed the laws. And there is nothing that more pacifies the people than the observing of the Laws.

And since one of the most important parts of the Laws or Constitution is this: that the ruler must be prepared to listen to and receive petitions[...] (Lütken 1759, 8-9).

Lütken obviously had no interest in advocating that the Danish King be admonished in a similar way to the Emperor of China, that people should regard his every word as an order from Heaven, and that he should have everyone kneel down before him when speaking, or even prostrate themselves before his personal effects. Lütken simply roughly translated the two initial lines about the emperor's authority and a few words about the "divine esteem" for the emperor. Then he added the rest himself about the obedient Chinese population and so on, claiming that the ancient historical records in China (which he does not specify and had obviously not read in the original) show that the fate of the emperors depended on whether they abided by the laws and the constitution, and in particular the law pertaining to the freedom of writing. Lütken used and re-worked Du Halde's text in a way that suited his political agenda, to promote the freedom of writing in Denmark, through showing that this had existed in China since ancient time, and was crucial for the fate of the emperor himself (and consequently also for the Danish monarch). Basing his arguments on Du Halde's work, he continues to claim that the wise emperors of China had allowed "that anyone may freely and clearly petition the emperor about what anyone regarded as useful for the Emperor to know" (Lütken 1759, 9).

Chydenius then translated Lütken's version of this very first passage of Du Halde's chapter 2 about the emperor's authority, quoted above, word by word from Danish, without considering the French original. Judging from Chydenius's translation of Lütken's text, he had no problem reading and translating contemporary Danish, which was very similar to Swedish, but he saw fit to make a few changes. Lütken $(1759,8)$ wrote: "Keiserne af China ere Enevolds herrer, og have en uomskraenket Magt $i$ alle Maader" [The Emperors of China are Absolute Sovereigns and have Absolute Power in all Respects]. Chydenius $(1766,9)$ then translated: 
"Kejsaren i China är en EnvåldsHerre, och äger värkligen en aldeles oinskränkt magt" [The Emperor of China is an Absolute Sovereign and Really Possesses Completely Absolute Power]. Chydenius thus changed plural to singular: "the Emperors" in Lütken's line became "the Emperor." He then replaced the word have [have] in Lütken's line for the stronger verb äger [possesses]. Then he added a few words, the grade adverbs värkligen [really] and aldeles [completely], which added substantially to the force of the statement. Finally, he omitted the last few words in Lütken's sentence $i$ alle Maader [in all respects].

I presume that Chydenius took the liberty to insert and subtract a few words to make the text and its argument more appealing to his intended readers. In this, and other sentences, he used pathos to appeal to his reader's emotions, especially to the future King of Sweden, to whom he had dedicated the pamphlet. This particular sentence is the first line of the main text in the pamphlet, the first line that meets the Prince's eye after the dedication. It appears that Chydenius wanted to emphasise that even though the Chinese Emperor was an absolute monarch who "really possesses completely absolute power" (unlike the Swedish King at that time), the Chinese Emperor still observed the law of the freedom of writing in China, that he listened to the voices of his people and obviously did not consider this an infringement on his authority. (Had Chydenius not removed the words "in all respects," it could have appeared somewhat contradictory, since with these citizen rights the monarch obviously did not "really possess completely absolute power" in "all respects"). Chydenius was careful in shaping the translation to suit his political agenda, using pathos to persuade and convince.

Example 2. Lütken chose to translate and re-work several passages in the "Imperial Collection" in Du Halde's vol. 2, providing instances of wise Emperors encouraging their officials to write or speak freely about matters of the State and thereby appearing to promote the freedom of writing. One such example is when "the Emperor Vou ti [Wudi, Emperor Wu]," in Du Halde's version, makes the following statement:

Here you see, Ta fou [dafu=senior officials], what my wishes are. As you are well versed in the most ancient antiquity, instructed in the foundation of the government of our ancient wise Princes and in all the recourses upon which depend the fortunes and misfortunes of the Empires: I do not at all doubt that you will give me great enlightenment on all that. But what I recommend to you is that in order to instruct me better, you shall proceed with order, without embracing too many things at the same time, without mixing up the matters, treating first one subject and then another, always proceeding step by step, and in every matter be well aware of what is most essential and most useful. Whatever you may have noticed in all the Officials of the Empire, like failing in virtue, failing in honesty, lack of zeal or enforcement, indicate it to me without omitting anything, and what regards my person, express yourselves freely, without disguise, without circumlocutions, and do not at all fear any unfortunate reprisals. Devote yourselves incessantly to drawing up a detailed memorandum. When it is ready, I will read it (Du Halde 1736, 2, 475; Transl. by J. Enwall). 
In this passage in Description de la Chine, the Emperor instructs his senior officials on how to write memoranda to him with advice on how to govern. Obviously, the Emperor is tired of elaborate memoranda that never seemed to get to the point, written by officials showing off their eloquence and learning. What the Emperor desires are short, well-structured and to the point memoranda with useful information. He also invites his senior officials to report on other officials that behave immorally, dishonestly and so on. The Emperor even invites them to criticise him (regardless of this "generous" offer, it is doubtful that the officials dared to do so, and no such instance is reported in this passage in Du Halde's text). Lütken, again, did not bother to translate this entire passage from Du Halde's work:

When the Emperor Vou ti wants to confirm this freedom [referring to the freedom of writing, according to Lütken], he says: "Do not think that I will be content with idle talk: I want to know the truth: Do not let either esteem or fear hold you back from speaking with frankness; since it is our will. Withhold me nothing, and when it concerns my own Person, speak freely, without hypocrisy and circumlocution, and fear no disfavor (Lütken, 1759, 12-13).

Lütken summarised only the content in this passage that suited his political agenda, without giving any clue to the context in Description de la Chine. In Du Halde's work, this passage contains instructions to officials on how to write memoranda, not to be printed and available to the public, but to be read by the Emperor himself. This has nothing to do with a general freedom of writing and of the press for each citizen that Lütken advocated in Denmark; it concerned simply the "Freedom of senior officials to write memoranda to the Emperor."

Nor does Lütken hesitate to put words in the Emperors mouth, such as the forceful warning by the Emperor in the quote above: "Do not think I will be content with idle talk: I want to know the truth." A forceful imperative like this by the Chinese Emperor would obviously have a stronger impact on readers in Denmark than the actual polite and detailed instructions by the Emperor on how to write memoranda concerning content and structure in Du Halde's original. In addition, the Emperor in Du Halde's text requires not specifically the absolute "truth" but what is "essential and useful." Lütken's choice of words here may be crucial for the debate in Denmark. A major argument in the debate on the freedom of writing and of the press in the Nordic countries by its advocates, centred on how this freedom would allow for the competition of ideas and arguments to reach the "truth," and how public debate might wipe out ignorance, prejudices and erroneous ideas when openly confronted by the "truth."

Finally, the Emperor's instruction in Du Halde's text to report on indecent and dishonest fellow officials is omitted by Lütken. It probably would not benefit Lütken's discourse on the freedom of writing and of the press in Denmark at that time that officials should be encouraged to use this freedom to turn each other in to the authorities.

This short and forceful passage in Lütken's version was probably exactly to Chydenius's taste and suited his political agenda perfectly, since he did not alter a single word when translating it $(1766,14)$. He did not have the opportunity to compare Lütken's translation with Du Halde's original, or if he did, he chose to ignore all the discrepancies. 
Example 3. Another passage in Description de la Chine that Lütken included, is a "public statement" in which "Emperor Hiao ven ti [Xiaowendi, Emperor Xiaowen]" asks for advice (Du Halde 1736, 2, 474).

Our intention is such, and we strongly wish that our subjects, from our highest Officials to the smallest, the simple literati, the merchants, the artisans and others, explain to us what they think is advantageous for the State, and capable of contributing to the happiness of the peoples. Even what they may consider as faulty in the present government and especially what to them seems to be able to harm good manners and virtue. I recommend them all, not only not to hide anything of that kind from me, but also to explain themselves freely and without circumlocutions. What I demand is not beautiful and long discourses, but good short and solid memoranda, so that I can look into them by myself. It shall be so much easier for those who will give them to me, to avoid the mistakes capable of offending me, and for me to draw the usefulness that I hope for in my instruction (Du Halde 1736, 2, 573-574, transl. by J. Enwall).

Obviously, "Emperor Hiao ven ti," just like "Emperor Vou ti" in Example 2, is instructing his officials to avoid elaborate "beautiful and long speeches," and instead write "short and solid memoranda." Lütken translated this passage as follows:

Likewise, the Emperor Hiao ven ti invites everyone [to do] the same[freely make petitions to the Emperor], when at the end of his command he says thus: It is therefore our serious intention and wish that all our subjects, from the premier to the basest, freely should reveal to us all that they consider to be beneficial for us to know, to be able to promote the happiness of our subjects. Conceal nothing from me, and speak right out about everything: be brief and without artificiality, so that I may myself investigate it and make use of it (Lütken 1759, 14).

Again, Lütken summarises but gives the impression that it is a translation of the exact words by the Emperor, turning it into a short, forceful imperative. Again, Lütken omits the context and does not mention that this "freedom of expression" concerns the writing of memoranda, not to be printed or public, merely to be read by the Emperor himself. It is again not a question of a general freedom of the press. Lütken also substitutes the word "officials" in "from our highest officials to the smallest" in Description de la Chine, for "subjects" and translates "all our subjects, from the premier to the basest," thereby giving the impression that this concerns a freedom of writing and of the press for every citizen of China. But even if the Emperor is asking all his subjects for advice (as in the title of the document in Du Halde's original $(1736,2,573)$, the Emperor in the quote above is basically instructing his officials how to write memoranda. And considering that even the minimal literacy rate in ancient China was extremely low, few others than the well-educated officials would be able to write a memorandum to the Emperor. Lütken obviously chose his words carefully in order to reinforce his political arguments for freedom of writing and of the press for each citizen in Denmark.

Lütken also omits the part about what is "advantageous for the State" in Du Halde's version, and translates only "contributing to the happiness of the peoples." And, just as in Example 2 above, he consistently omits the part about allowing 
officials to report on errors by the present government and criticise their faults. He probably realised that this would not be an attractive feature of the freedom of writing and of the press for Danish politicians and government officials. They rather needed to be convinced about the merits of the freedom of the press, and not fear that such a freedom would open up for criticism of themselves.

Chydenius in turn provides a word-for-word translation of Lütken's text with just a little change of words in the initial line. Lütken $(1759,14)$ wrote: "Likewise, the Emperor Hiao ven ti invites everyone [to do] the same [freely make petitions to the emperor], when at the end of his command he says thus ..." Chydenius $(1766,15)$ then translated: "Likewise, the Emperor Hiao ven ti demands the same thing, when at the end of his ordinance he states thus ..." By replacing the word the Emperor "invites" with the Emperor "demands," Chydenius again makes the Emperor's statement more forceful. In addition, Chydenius replaces the word "command" in Lütken's text with "ordinance," in Swedish "förordning." 12 By choosing to use the word "ordinance," Chydenius would like to give the impression that this was not some kind of random command issued by the Emperor but rather a statutory text, that the freedom of expression was part of Chinese law. So what started out as basically a "public statement" with a "recommendation" by the Emperor in Description de la Chine to his officials on how to write "good short and solid memoranda" with "useful" information, had by the time it reached Chydenius through Lütken turned into a statutory text, an "ordinance" about the freedom of expression for all citizens.

One may ask how representative these passage in Du Halde's work, which Lütken, and then Chydenius used for their political propaganda, really are. These kinds of statements by emperors encouraging their officials to offer advice on state matters, to criticise the government or even the emperor himself, in memoranda written to the throne, constitute a fraction of the almost 3000 pages in Du Halde's four volumes. (And there are plenty of examples of emperors not acting so wisely). The passage about the "Emperor Hiao ven ti" in Example 3, for instance, is followed by a chapter which relates how the "Emperor Suen vou ti" [Xuanwudi, Emperor Xuanwu] was presented with a chicken that had four wings and four legs (Du Halde 1736, 2, 574-575). The Emperor then asked his senior official how to regard this matter, who immediately saw this as an omen, a sign that something in the Kingdom was not right. He advised the Emperor that great disaster and trouble would occur if the Emperor did not change his ways of governing. The Emperor followed this advice. This passage was naturally omitted by Lütken. Nor would this episode have appealed to Chydenius, who argued that the truth was obtained through the competition of arguments and ideas in public debate and print. The fact that the appearance of a deformed chicken could qualify as evidence against a certain way of governing in China, would hardly have impressed Chydenius's political adversaries in the Swedish Diet at the time of the debate on the freedom of the press. Relating such an incident would rather tarnish the image of the wise and enlightened rulers of China and diminish the credibility and impact of Berättelse om Chinesiska Skrif-friheten.

\section{Conclusion}

In this article I have shown how the Swedish 18th-century politicians Anders Nordencrantz and Anders Chydenius (and Chydenius's source the Danish writer 
Lütken) used the descriptions of China in Du Halde's Description de la Chine to create an image of China as a land of freedom of writing, of the press and of information in order to promote the freedom of writing, of the press and of information in Sweden (and Lütken in Denmark). Nordencrantz "copy-pasted" only parts of the information about the Peking Gazette in Description de la Chine in his political pamphlet Oförgripeliga tankar om Frihet i bruk af Förnuft, pennor och Tryck. He omitted the parts that would have been detrimental to his political agenda, such as the information of the penalties for expressing any kind of reflections on government issues in China, which was also recorded by Du Halde. Through the dedication of his pamphlet and by adding, omitting or substituting words when translating Lütken's already severely distorted version of Du Halde's work, Chydenius shaped an image of China that fitted his political agenda, the Swedish debate at the time and the intended readers. His use of pathos made the text's argument more appealing to one most important intended reader, the future King of Sweden. In Berättelse om Chinesiska Skrif-friheten Chydenius created an image of China in which all China's wealth, perseverance and wise rule, the well-being of the Chinese people, of the Chinese empire, and even of the Emperor himself, rested largely on an ancient law of the freedom of writing, of the press and of information, that the Swedish Crown Prince and Diet should also be wise to accept.

This image of China was very far from the reality of authoritarian 18th-century China. Initially, this image was created by Du Halde, a work in itself quite removed both from the original Chinese and Western sources and the Chinese reality, since it presents a highly selective and biased image of conditions in China. And every step in the citing, or translation of Du Halde's work, through Danish, and then into Swedish, moved the image of China even further away from contemporary Chinese reality and more towards an image of China that served the political purposes of the writers of these political pamphlets, Anders Nordencrantz and Anders Chydenius.

So a distorted image of China as being the foremost land of the freedom of writing, of the press and of information, based on writings by French Jesuits, and adapted and used as political argument by politicians in Sweden (and Denmark) in the 18th century, contributed to the passing of the first Freedom of Writing, of Press and of Information Act in the Swedish Diet, the first FOIA in the world. Globalisation as we know it is far from a new phenomenon. Conceptions as well as misconceptions about other cultures and political systems have shaped our values, politics and societies in more ways than we imagine.

\section{Acknowledgments}

I would like to thank Prof. Marie-Christine Skuncke for valuable comments on the draft of this paper. I would also like to thank Prof. Joakim Enwall for his translations of two of the quotations from Du Halde's original work in French into English in Examples 2 and 3.

\section{Notes:}

1. Available in English translation by Peter Hogg (2006). All other translations from Swedish and Danish sources into English in this paper were made by the author unless otherwise stated.

2. Professor Skuncke has published several articles on this topic, for instance: "Kina var viktigt för 1700-talets Sverige" [China was important for 18th century Sweden] (2002) and "La liberté dans la culture politique suédoise au XVIII siècle" (2003). 
3. The first complete translation of Du Halde's Description de la Chine was printed for Edward Cave in London in 1738 (Löwendahl 2008, 190).

4. However, when one of Nordencrantz political opponents published a criticism of one of his books, Nordencrantz was furious and demanded that the critic be punished by the court system for "slandering a Diet member in public print" (Lindqvist 1996, 34).

5. Nordencrantz's statement in a political pamphlet denied printing in 1756 , quoted by Lindqvist (1996, 407-8).

6. Anders Chydenius's Sjelfbiografi [Autobiography] $(1780,434)$ quoted by Virrankoski $(1995,179)$.

7. Ibid.

8. Berättelse om Chinesiska Skrif-friheten was printed by Lars Salvius, probably in the beginning of April 1766, since it is introduced in Lärda Tidningar [Erudite journals] No 30, 1766, by Salvius on the 17th of April (Virrankoski 1995, 187, f 32).

9. The author and title of the Danish original text are never mentioned in Berättelse om Chinesiska Skrif-friheten, but when comparing the text it is obviously a translation from Lütken's work. Neither Lütken's work, nor Berättelse om Chinesiska Skrif-friheten are mentioned in Löwendahl's (2008) bibliography Sino-Western relations, conceptions of China, cultural influences and the development of sinology: Disclosed in Western printed books 1477-1872.

10. According to Löwendahl (2008), pp 389-612 in vol. 2 of Description de la Chine (1735) are based on Xu Qianxue's Yuxuan guwen yuan jian. The "Imperial collection" section was not included in Watts's English editions.

11. These first lines in the original: “II n'y a jamais eu d'Etat plus monarchique que celui de la Chine: l'Empereur a une autorité absolue; \& à en juger par les apparences, c'est une espèce de divinite: Le respect qu'on a pour lui, va jusqu'à l'adoration" (Du Halde 1736, 2, 10).

12. The entire line in Swedish: “Likaledes yrkar Kejser Hiao ven ti på det samma, då han i slutet af sin Förordning yttrar sig således"(Chydenius 1766, 15).

\section{References:}

Chydenius, Anders. 1766. Berättelse om Chinesiska Skrif-friheten: Öfversatt af danskan. Stockholm. Chydenius, Anders. 1765. Källan til Rikets wan-magt. Stockholm.

Du Halde, Jean Baptiste.1736. Description géographique, historique, chronologique, politique, et physique de l'empire de la Chine et de la Tartarie chinoise, Vol 2. La Haye: chez Henri Scheurleer. Quarto edition.

Fang, Hanqi, ed. [1992]1997. Zhongguo xinwen shiye tongshi [General History of Chinese Journalism]. Beijing: Zhongguo renmin daxue chubanshe. Vol 1.

Hallberg, Peter. 2003. Den förlorade friheten: Historieskrivning och samhällskritik under sen frihetstid. In M.C. Skuncke and H. Tandefelt (eds.), Riksdag, Kaffehus och Predikstol: frihetstidens politiska kultur 1766-1772, 339-352. Helsingfors: Svenska litteratursällskapet i Finland.

Herlitz, Lars. 2003. Nordencrantz, Christiernin och den monetära debatten på 1760-talet. In M-C. Skuncke and H. Tandefelt (eds.), Riksdag, Kaffehus och Predikstol: frihetstidens politiska kultur 1766-1772, 131-142. Helsingfors: Svenska litteratursällskapet i Finland.

Hogg, Peter. 2006. Translation of His Majesty's Gracious Ordinance Relating to Freedom of Writing and of the Press (1766). In J. Mustonen (ed.), The World's First Freedom of Information Act: Anders Chydenius' Legacy Today, 8-17. <http://www.chydenius.net/pdf/worlds_first_foia.pdf >

Klinge, Matti. 2003. Republikaner redan i unga år: Gymnasiekamrater från Borgå. In M-C. Skuncke and H. Tandefelt (eds.), Riksdag, Kaffehus och Predikstol: frihetstidens politiska kultur 1766-1772, 105-128. Helsingfors: Svenska litteratursällskapet i Finland.

Knif, Henrik. 2003. Den farliga staden. Anders Chydenius och Stockholm. In M.-C. Skuncke and H. Tandefelt (eds.), Riksdag, Kaffehus och Predikstol: frihetstidens politiska kultur 1766-1772, 155169. Helsingfors: Svenska litteratursällskapet i Finland.

Lindberg, Bo. 2003. Inledning: Politisk kultur och idéer. In M.-C. Skuncke and H. Tandefelt (eds.), Riksdag, Kaffehus och Predikstol: frihetstidens politiska kultur 1766-1772, 13-22. Helsingfors: Svenska litteratursällskapet i Finland. 
Lindqvist, Herman. 1996. Historien om Sverige: Nyttan och nöjet. Stockholm: Nordstedts.

Lütken, Friderik. 1759. Oeconomiske Tanker til höiere Efter-Tanke, Vol 6. Kiöbenhavn: Nicolaus Möller.

Löwendahl, Björn. 2008. Sino-Western Relations, Conceptions of China, Cultural Influences and the Development of Sinology: Disclosed in Western Printed Books 1477-1872: The Catalogue of the Löwendahl-von der Burg Collection, Vol 1. Hua Hin: Elephant Press.

Magnusson, Lars. 2003. Den ekonomiska diskussionen under frihetstiden- ett framlängesperspektiv. In M.-C. Skuncke and H. Tandefelt (eds.), Riksdag, Kaffehus och Predikstol: frihetstidens politiska kultur 1766-1772, 25-38. Helsingfors: Svenska litteratursällskapet i Finland.

Malmström, Carl Gustaf. 1900. Sveriges politiska historia: Från Konung Karl XIl:s död till Statshvälfningen 1772, Vol 5. Stockholm: P.A. Nordstedt \& söners förlag.

Manninen, Juha. 2006. Anders Chydenius and the Origins of the World's First Freedom of Information Act. In J. Mustonen (ed.), The World's First Freedom of Information Act: Anders Chydenius' Legacy Today, 18-53. Anders Chydenius Foundation. <http://www.chydenius.net/ pdf/worlds_first_foia.pdf >

Nordencrantz, Anders. 1756. Oförgripelige tankar om Frihet i bruk af Förnuft, Pennor och Tryck, samt huru långt Friheten derutinnan i et fritt Samhälle sig sträcka bör, tillika med påfölgden deraf. Stockholm.

Nordencrantz, Anders.1759. Til Riksens Höglofl. Ständer Församlade Wid Riksdagen År 1760. En Wördsam Föreställning [...]. Stockholm.

Nurmiainen, Jouko. 2003. Gemensamma privilegier för ett odalstånd: Alexander Kepplerus som borgmästare och samhällstänkare. In M.-C. Skuncke and H. Tandefelt (eds.), Riksdag, Kaffehus och Predikstol: frihetstidens politiska kultur 1766-1772, 171-190. Helsingfors: Svenska litteratursällskapet i Finland.

Schauman, Georg. 1908. Biografiska undersökningar om Anders Chydenius: jämte otryckte skrifter av Chydenius. Helsingfors: Svenska litteratursällskapet i Finland.

Skuncke, Marie-Christine. 2002. Kina var viktigt för 1700-talets Sverige. Svenska Dagbladet, March 3. <http://www.svd.se/kulturnoje/nyheter/artikel_45413.svd>

Skuncke, Marie-Christine. 2003. La liberté dans la culture politique suédoise au XVIII siècle. In A.Grzeskowiak-Krwawicz and I. Zatorska (eds.), Liberté: Héritage du passé ou idée des lumières?, 28-41. Kraków: Collegium Columbinum.

Skuncke, Marie-Christine. 2004. Press and Political Culture in Sweden at the End of the Age of Liberty. In H-J. Lüsebrink and J.D. Popkin (eds.), Enlightenment, Revolution and the Periodical Press, 81-101. Oxford: Voltaire Foundation.

Virrankoski, Pentti; Translation: Lindén, Jan Ivar, and Joachim Mickwitz. 1995. Anders Chydenius: demokratisk politiker i upplysningens tid. Stockholm: Timbro.

Watts, J. 1741. The General History of China: Containing a Geographical, Historical, Chronological, Political and Physical Description of the Empire of China, Chinese-Tartary, Corea and Thibet, Including an Exact and Particular Account of Their Customs, Manners, Ceremonies, Religion, Arts and Sciences. Third corrected edition. Vol. 2. London: J. Watts.

Zilliacus, Clas and Henrik Knif. 1985. Opinionens tryck: en studie över pressens bildningsskede i Finland. Helsingfors: Svenska litteratursällskapet i Finland. 